\begin{tabular}{c}
\hline \hline OPEN \\
JOURNAL \\
SYSTEMS \\
\hline \hline ISSN:2237-2202
\end{tabular}

Available on line at Directory of Open Access Journals

Journal of Hyperspectral Remote Sensing v.9, n.6 (2019) 361-372

www.periodicos.ufpe.br/revistas/jhrs

\section{Journal of \\ Hyperspectral \\ Remote Sensing}

\title{
Downscale of future climate change scenarios applied to Recife-PE
}

\author{
Rafaela L. Costa*; Heliofábio B. Gomes**; Fabrício D. dos S. Silva***; Rodrigo L. da Rocha Júnior ${ }^{* * * *}$ \\ *PNPD Scholarship in the Postgraduate Program in Meteorology -PPGMET/ICAT/UFAL. Email: rafaelalisboac@gmail.com \\ (Corresponding author) \\ ** Prof. Dr in the Postgraduate Program in Meteorology -PPGMET/ICAT/UFAL. Email: heliofabio@icat.ufal.br \\ ****Prof. Dr in the Postgraduate Program in Meteorology - PPGMET/ICAT/UFAL. Email: fabricio.santos@icat.ufal.br \\ ***** Master Student in the Postgraduate Program in Meteorology -PPGMET/ICAT/UFAL. Email: rrodrigo.junior@ hotmail.com
}

Received 16 September 2019, accepted 12 October 2019

\begin{abstract}
The objective of this work was to analyze and compare results from two generations of global climate models (GCMs) simulations for the city of Recife-PE: CMIP3 and CMIP5. Differences and similarities in historical and future climate simulations are presented for four GCMs using CMIP3 scenarios A1B and A2 and for seven CMIP5 scenarios RCP4.5 and RCP8.5. The scale reduction technique applied to GCMs scenarios is statistical downscaling, employing the same set of large-scale atmospheric variables as predictors for both sets of scenarios, differing only in the type of reanalysis data used to characterize surface variables rainfall, maximum and minimum temperatures. For CMIP3 scenarios the simulated historical climate is 1961 1990 and CMIP5 is 1979-2000, and the validation period is ten years, 1991-2000 for CMIP3 and 2001-2010 for CMIP5. However, for both the future period analyzed is 2021-2050 and 2051-2080. Validation metrics indicated superior results from the historical simulations of CMIP5 over those of CMIP3 for rainfall and minimum and similar temperatures for maximum temperatures. For the future, both CMIP3 and CMIP5 scenarios indicate reduced rainfall and increased temperatures. The potencial evapotranspiration was calculated, projected to increase in scenarios A1B and A2 of CMIP3 and with behavior similar to that observed historically in scenarios RCP4.5 and 8.5.

Keywords: rainfall, temperature, potential evapotranspiration, statistical downscaling.
\end{abstract}

\section{Introduction}

Global Climate Models (GCMs) have been developed and improved to generate feasible projections of future climate, based on the current outlook of greenhouse gas emission trends, for scenarios that favour stabilization/reduction of emissions, as well as climate change for chaotic scenarios where the world's population will intensify fossil fuel use without any control effort. These scenarios are updated to improve understanding of what may happen to future climate according to the anthropic influence on the current climate, according to various environmental parameters compiled by the Intergovernmental Panel on Climate Change (IPCC) team, which investigates climate change ongoing on the planet (Silva et al., 2013).

For the northeastern region of Brazil, recent studies (Marengo et al., 2009; Sales et al., 2015; Guimarães et al., 2016) show that there is a predominantly positive trend in increasing temperatures, especially minimum temperatures, decreasing the amplitude, which should directly increase the potential evapotranspiration (PET) of this region.
The increase in PET associated with the wellknown high spatiotemporal variability of rainfall can further impair agricultural activities, notably rainfed, as well as increasing the demand for water in irrigated crops (Salviano et al., 2016).

This research aims to analyse future climate scenarios and evaluate the impacts on the distribution of the variables rainfall, temperature and potential evapotranspiration for the horizon 2021-2080, from the comparison of the historical and future climate simulations produced by phases 3 and 5 of the Coupled-Model Intercomparison Project (CMIP3 and CMIP5), respectively.

The place of application of this study is the city of Recife, capital of Pernambuco State, a city with an estimated 1,645,727 inhabitants for 2019 by the IBGE. The metropolitan region of Recife is characterized by its high vulnerability to natural disasters caused by floods (Souza et al., 2014; Borges et al., 2016). Detailed studies of recent climate change associated with future regionalized climate change scenarios allow us to analyse the degree of magnitude that these changes may affect a particular locality. In this sense, the present research was developed in order to achieve the following objectives: to validate the 
statistical downscalling of rainfall, temperatures and PET for the city of Recife, from GCM forecasts, for two different future greenhouse gas emission scenarios, greenhouse, A1B and A2 of the fourth IPCC report (CMIP3), and RCP4.5 and 8.5 of the fifth IPCC report, period 2021-2080.

\section{Materials and methods}

\section{Study area}

According to Souza et al. (2014), the municipality of Recife-PE (Lat.$: 8^{\circ} 04^{\prime} 03$ "S; Long .: $34^{\circ} 55^{\prime} 00^{\prime \prime} \mathrm{W}$; Alt .: $4 \mathrm{~m}$ ) is located on the northeastern coast with a territorial surface of $219,493 \mathrm{~km} 2$, consisting of hills (67.43\%), plains (23.26\%) and aquatic zones $(9.31 \%)$, with special emphasis on Environmental Preservation ZEPA (5.58\%) and an extension beach of $8.6 \mathrm{~km} 2$ (Prefeitura do Recife, 2008).

Figure 1 shows the spatial location of Recife in the state of Pernambuco.

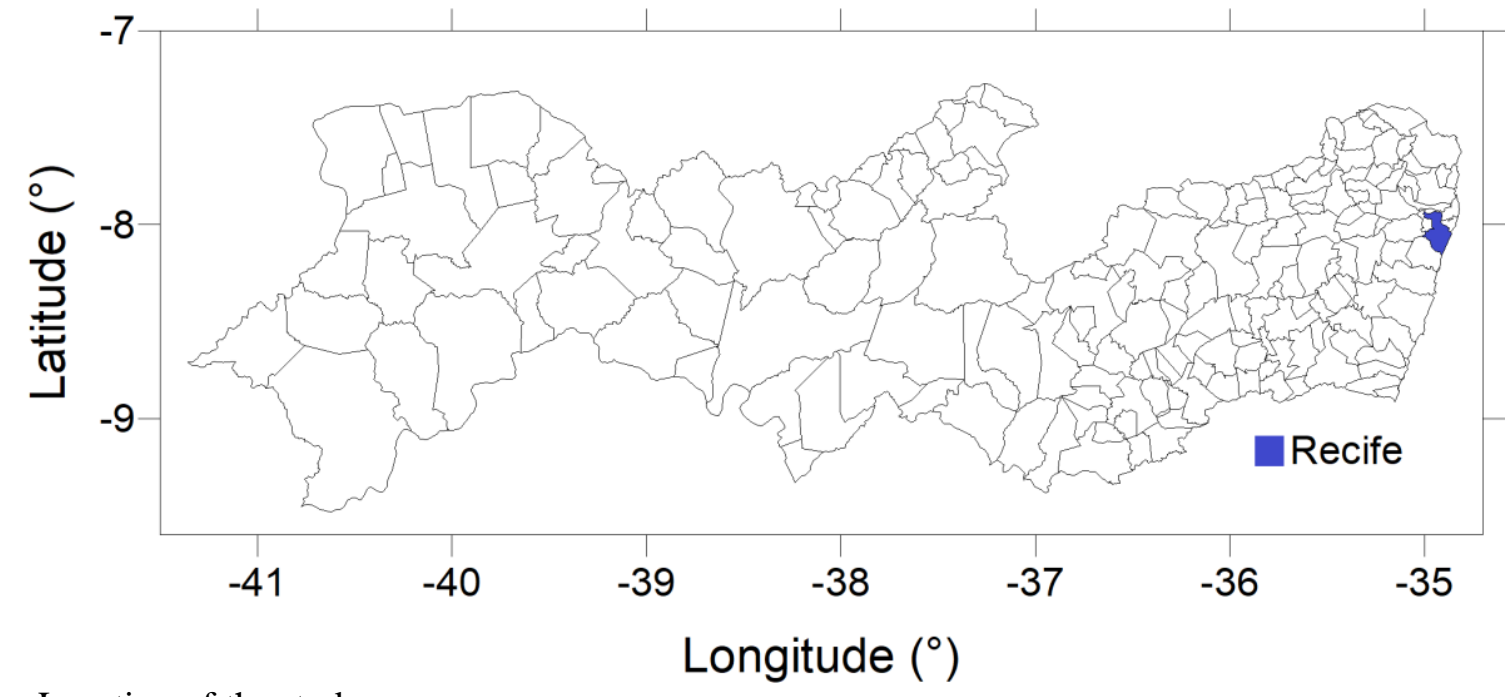

Figure 1 - Location of the study area.

\section{Observed Data}

Daily rainfall data, maximum and minimum temperatures from the National Institute of Meteorology (INMET) from 1961-2010 were used. For calibration and validation of the historical climate of the CMIP3 GCMs, the observation subperiods 1961-1990 and 1991-2000 were selected, while for the CMIP5 GCMs, the observation subperiods 1979-2000 and 2001-2010 were selected. The data underwent strict quality control (Silva et al., 2014) and the data had their failures filled in according to Carvalho et al. (2016).

\section{Climate Change Scenarios}

GCMs have evolved over the past decades to incorporate greenhouse gas emissions data to meet IPCC demand and generate future climate projections over horizons that may extend beyond the end of the century (Vannitsem and Chome, 2005; Jones et al., 2004). These future projections are carried out in accordance with climate change scenarios designed by the IPCC regarding the most likely evolutionary patterns of humanity in the consumption of fossil fuels and carbon dioxide emissions, carbon monoxide, nitrous oxide, sulfur dioxide, methane, among other gases (Nakicenovic et al., 2000; SRES, 2010).
In this research we worked on scenarios $\mathrm{A} 1 \mathrm{~B}$ and A2 of the fourth IPCC report (CMIP3), and scenarios RCP4.5 and 8.5 of the fifth IPCC report (CMIP5).

The A1B scenario describes a future world of very rapid economic growth, low population growth, and the rapid introduction of new and more efficient technologies, with a balanced emphasis on all energy sources. Major underlying themes are convergence among regions, capacity building, and increased cultural and social interactions, with a substantial reduction in regional differences in per capita income. The A2 scenario describes a very heterogeneous world. The underlying theme is self-reliance and preservation of local identities. Fertility patterns across regions converge very slowly, which results in high population growth. Economic development is primarily regionally oriented and per capita economic growth and technological change are more fragmented and slower than in other storylines (SRES, 2010).

Scenarios RCP4.5 and RCP8.5 are part of the new scenario family (van Vuuren et al., 2009). They represent an evolution of the previous scenarios by incorporating into the forcing social-political emission profiles based on protocols of agreements signed by nations regarding the implementation of public 
policies aimed at minimizing greenhouse gas emissions.

RCP4.5 provides a climate forcing that reaches $4.5 \mathrm{~W} / \mathrm{m} 2$ by 2050 , with further stabilization. The worst case scenario is RCP8.5, with continued growth of the radiative forcing to reach $8.5 \mathrm{~W} / \mathrm{m} 2$ by 2100 (Fujino et al., 2006; Smith and Wigley, 2006; van Vuuren et al., 2006, 2007a, b, 2011; Clarke et al., 2007; Riahi et al., 2007, 2011; Hijioka et al., 2008; Wise et al., 2009).

\section{GCMs and Statistical Downscaling Model}

In this research four CMIP3 GCMs were used for scenarios A1B and A2: ECHAM5-OM of the Max Planck Institute for Meteorology of Germany (Marsland et al., 2003; Raddatz et al., 2007); HadGEM2-ES, from the United Kingdom Meteorological Office Hadley Center (Bellouin et al., 2007; Collins et al., 2008); BCM version 2 of the Bjerknes Center for Climate Research (BCCR) at the University of Bergen, Norway; and CNRM-CM3 of the French National Center for Meteorological Research. A brief description of each GCM is provided below.

ECHAM5-OM consists of the coupling of an atmospheric GCM (ECHAM5) and an ocean-sea ice component. ECHAM5 is the fifth generation of GCM ECHAM, originally evolving from the European Center for Medium Term Forecasting (ECMWF) spectral weather forecasting model. Its atmospheric prognostic variables are vorticity, divergence, temperature, pressure, water vapor, liquid cloud water and cloud ice. Its spatial resolution is 63 levels of horizontal resolution and 31 levels of vertical resolution. Ocean resolution of $1.5^{\circ}$ with 40 levels.

HadGEM2-ES is a coupled model of the ground system used by the Met Office Hadley Center for simulations throughout the century. This model comprises an atmospheric GCM with 96 horizontal resolution levels and 38 vertical resolution levels, and an ocean GCM with $1^{\circ}$ horizontal resolution (increasing to $0.33^{\circ}$ at the equator) and 40 vertical levels.

BCM version 2 of the Bjerknes Center for Climate Research (BCCR) is a coupled model of the terrestrial system, with the sea ice model coupled with the oceanic model. The atmospheric GCM contains 63 levels of horizontal resolution and 31 levels of vertical resolution, with triangular truncation whose spatial resolution equals $2.8^{\circ}$. The oceanic GCM has 35 vertical layers and approximately square horizontal grid cells with $1.5^{\circ}$ spacing along the equator in an Arakawa C grid.

CNRM-CM3 is a coupled ocean-atmospheresea ice model belonging to Metéo-France. Its atmospheric resolution is triangular truncation to 63 levels of horizontal resolution equivalent to $2.8^{\circ}, 45$ vertical layers with 23 layers above $200 \mathrm{hPa}$ and 7 below $850 \mathrm{hPa}$. The ocean resolution is $182 \mathrm{X} 152 \mathrm{grid}$ points, with a resolution of approximately $2^{\circ}$ long and ranging from approximately $0.5^{\circ}$ near the equator to $2^{\circ}$ near the poles in Arakawa $\mathrm{C}$ grid.

For scenarios RCP4.5 and 8.5, seven CMIP5 GCMs were used: CANESM2, from the Canadian Center for Climate Modeling and Analysis-Canada; CNRM-CM5, Center National de Recherches Météorologiques-France; GFDL-ESM2M of the National Oceanic and Atmospheric AdministrationUnited States; IPSL-CM5A-MR from Institut Pierre Simon Laplace-France; MIROC-SEM, developed by Tokyo University and partners-Japan; MPI-ESM-MR from Max-Planck-Institut fur Meteorologie-Germany, and NORESM1-M from the Norwegian Climate Center's Earth System Model-Norway. Brief description of each GCM is provided below.

CANESM2 is the second generation Canadian model of the CANESM terrestrial system, consisting of an ocean-atmosphere coupled physical model - CanCM4, a terrestrial carbon model - CTEM, and oceanic model - CMOC. The terrestrial and oceanic components of the carbon cycle work in two ways, in the first anthropogenic emissions of $\mathrm{CO} 2$ they are interactively specified and the model is able to simulate the evolution of atmospheric $\mathrm{CO} 2$ content. In the second, the earth-atmosphere and oceanatmosphere $\mathrm{CO} 2$ fluxes remain determined and the model results can be used to diagnose anthropogenic CO2 emissions (Zahariev et al., 2008; Arora et al., 2009; Arora and Boer, 2010).

CNRM-CM5 is an evolution of the CNRMCM3 ground system model designed to perform climate simulations. Composed of several independent and coupled models. The atmospheric model is ARPEGE-Climate, NEMO is the ocean model, GELATO the sea ice model, the land flow model is the SURFEX, and the water loading and discharging model between rivers and oceans is the TRIP. The CNRM-CM5 is able to simulate the current climate and its variability over time scales ranging from months to centuries, simulating future climate depending on greenhouse gas scenarios. Incorporated into the model are the effects of atmospheric aerosols, variations in solar irradiance, and the impact of large volcanic eruptions (Salas-Meliá, 2002; Salas-Meliá et al., 2005; Voldoire at al., 2011).

GFDL-ESM2M is the model developed by the National Oceanic and Atmospheric Administration Geophysical Flui Dynamics Laboratory, based on atmospheric circulation models associated with oceanic models, with representations of land dynamics, sea ice and icebergs, and interactive biogeochemistry including carbon. The atmospheric module includes the physical characteristics of natural and anthropogenic aerosols, cloud physics and 
rainfall. The terrestrial component includes the water balance. The ocean component includes wave processes, currents, sea ice dynamics, freshwater iceberg transport, biogeochemistry and marine ecology. Emission scenarios are used to assess the impact of a range of human activities on the atmosphere, hydrosphere, cryosphere, earth surface and biosphere (Dunne et al., 2012; Taylor et al., 2012; Dunne et al., 2013).

IPSL-CM5A-MR is developed by the Institut Pierre-Simon-Laplace (IPSL), a consortium of research laboratories dedicated to the study of the climate system and the global environment. It includes 5 models representing the earth's climate and its carbon cycle: LMDZ (Atmosphere), NEMO (Ocean, Ocean Biogeochemistry and Sea Ice), ORCHIDEE (Surfaces and Continental Vegetation) and INCA (Atmospheric Chemistry). The system that attaches all modules is OASIS. The IPSL-CM5A-MR is the midresolution version of the IPSL-CM5A ground system model. The resolution is $1.25^{\circ} \mathrm{x} 2.5^{\circ}$ with 39 vertical levels for the atmosphere and 31 vertical levels for the ocean. This is an enhanced version for CMIP5 of IPSL-CM4 used for CMIP3 (Dufresne et al., 2013).

MIROC-ESM is based on GCM MIROC, developed at the University of Tokyo. It involves the MIROC-AGCM2010 general atmospheric circulation model, which includes the SPRINTARS5.00 aerosol component, an ocean-based GCM with COCO3.4 sea ice component and a MATSIRO ground surface model. MIROC-ESM contains an atmospheric chemistry module, one of the ocean and terrestrial ecosystem that dynamically treats vegetation. MIROC-AGCM has a dynamic spectral core and uses a semi-Lagrangian scheme for flow advection. Its triangular truncation has a total number of 42 horizontal waves, with a grid of approximately 2.8125 degrees latitude-longitude. It uses the 80-layer sigma vertical coordinate system (Nozawa et al., 2007; Watanabe et al., 2011).

MPI-ESM-MR is a medium resolution version of the MPI-ESM ground system model developed by the Max-Planck Institute. It has atmospheric (ECHAM6), oceanic (MPI-OM), terrestrial surface (JBASCH) and ocean biogeochemistry modules. These components are coupled through the exchanges of energy, momentum, water and gases such as carbon dioxide. It was developed based on the ECHAM5-MPI-OM predecessor models and their COSMO versions. ECHAM5-MPI-OM was used in CMIP3 simulations. It has an aerosol and chemistry module (HAMMOZ) and is used in over 45 institutions worldwide (Giorgetta et al., 2013; Jungclaus et al., 2013; Muller et al., 2018).

NORESM1-M is the intermediate version of the NORESM model, with a horizontal resolution of $2^{\circ}$ for the atmospheric module and $1^{\circ}$ for the ocean and ice module. This version is used to provide results for the CMIP5, has a module to simulate the carbon cycle and is based on the CCSM4 model operated by NCAR, oceanic model MICOM, and extended atmospheric model with online aerosol calculation and its direct effects and indirect in warm clouds (Bentsen et al., 2012; Iversen et al., 2013, Guo et al., 2019).

All of these GCMs have different spatial resolutions whose grid spacing can encompass several surface station points. Statistical downscaling is a technique that allows large-scale information of GCMs to be brought to the local scale by obtaining predictor-predictive relationships, ie it allows selecting and obtaining the best combination of atmospheric and oceanic variables of the GCMs that respond. by surface variables such as rainfall and temperature in the most satisfactory way. The analogous method was used (Gutierrez et al., 2013), where similarity patterns are filtered by empirical orthogonal functions.

Initially, all GCMs need to be scaled to the same regular grid, combining with reanalysis data in order to select the best predictors for reanalysis surface variables. These will be the predictors used to calibrate/validate the statistical downscaling model for time series of observed rainfall and temperature data from weather stations (Cofiño et al., 2007; Wilby and Dawson, 2013).

For CMIP3 models, the ERA40 for rainfall and NCEP/NCAR for temperature re-analyzes were used (Hartmann et al., 2013). For the CMIP5 models, the ECMWF ETA-Interim reanalysis (Dee et al., 2011) was used for both variables. The historical climate calibration period of the CMIP3 models was 1961-1990 and the CMIP5 models was 1979-2000, and their validation periods were 1991-2000 and 2001-2010, respectively. For rainfall, the large-scale predictor variables of the GCMs were the southern component of the $850 \mathrm{hPa}$ mean wind speed, the zonal component of the $850 \mathrm{hPa}$ mean wind speed, the specific humidity at the $850 \mathrm{hPa}$ level, mean sea level pressure, $500 \mathrm{hPa}$ geopotential and $850 \mathrm{hPa}$ temperature. For the temperatures, the predictor variables were selected specific humidity at $850 \mathrm{hPa}$ level, mean sea level pressure, geopotential at $500 \mathrm{hPa}$ level and temperature at $850 \mathrm{hPa}$ level.

\section{Model Performance Evaluation}

The GCMs were evaluated for their ability to simulate the historical climate, that is, if the climatological normals from the GCMs were compared to those observed. The GCMs were also evaluated jointly from the average of all models, a technique known as ensemble. The main validation and performance metrics of the GCMs were mean () and standard deviation (S), descriptive statistics 
measures; correlation coefficient (r) and root mean square error (RMSE), precision measurements, variance ratio (RV) and PDFescore (PDFesc), data distribution similarity measures.

\section{Potential Evapotranspiration}

Potential evapotranspiration (ETP) was obtained by the method of Hargreaves and Samani (1985), which only requires temperature and solar radiation data (Samani, 2000), given by the following simplified formula:

$$
\mathrm{ET}_{\mathrm{P}}=0,0023\left(\mathrm{~T}_{\text {med }}+17,78\right) \cdot \mathrm{R}_{0} \bullet\left(\mathrm{T}_{\max }-\mathrm{T}_{\text {min }}\right)^{0,5}
$$

where: $\mathrm{ET}_{0}=$ potential daily evapotranspiration $(\mathrm{mm} /$ day $)$, Tmed $=$ average daily temperature $\left({ }^{\circ} \mathrm{C}\right), \mathrm{R} 0$ $=$ extraterrestrial solar radiation, in $\mathrm{mm} /$ day (tabulated), Tmax = maximum daily temperature and Tmin $=$ minimum daily temperature $\left(\right.$ both in $\left.{ }^{\circ} \mathrm{C}\right)$.

To evaluate $\mathrm{R}_{0}$ there are several tables, all depending on latitude and month. For the city of Recife, located at $8.0675^{\circ}$ latitude, monthly average values of $\mathrm{R} 0$ of the latitude of $8^{\circ}$ provided by Allen et al (1998) in mm/day (evaporated water) were used.

Tabela 1 - Extraterrestrial solar radiation in mm/day to Recife $\left(\sim 8^{\circ} \mathrm{S}\right)($ Allen et al., 1998$)\left(\mathrm{MJ} \cdot \mathrm{m}^{-2} \cdot \mathrm{dia}^{-1} ; 1\right.$ $\mathrm{mm} / \mathrm{dia}=2,45 \mathrm{MJ} \cdot \mathrm{m}^{-2} \cdot \mathrm{dia}^{-1}$ ).

\begin{tabular}{llllllllllll}
\hline Jan & Feb & Mar & Apr & May & Jun & Jul & Agu & Sep & Oct & Nov & Dec \\
\hline 15,9 & 15,9 & 15,5 & 14,3 & 13,0 & 12,2 & 12,5 & 13,6 & 14,9 & 15,7 & 15,8 & 15,8 \\
\hline
\end{tabular}

\section{Results and discussion}

\section{Historical Climate Simulation}

The first step in working confidently with future-weather GCMs is to see if they are able to simulate the historical climate of a reference period. Figures 2 and 3 show this GCM's ability to represent the historical climate of the period 1961-1990 (CMIP3) and 1979-2000 (CMIP5). Both CMIP3 and CMIP5 GCMs underestimate rainfall in some months of the wettest period of the year between March and
August, and overestimate average rainfall in the driest months of the year between September and February. These slight differences compensate and the annual accumulation is very similar between observations and ensemble. The average annual cycle of maximum temperatures was very well simulated by the GCMs. For minimum temperatures, the CMIP5 models presented climatological values closer to the observation than the CMIP3 models, which overestimated the climatological average in May, June, August, September and October.
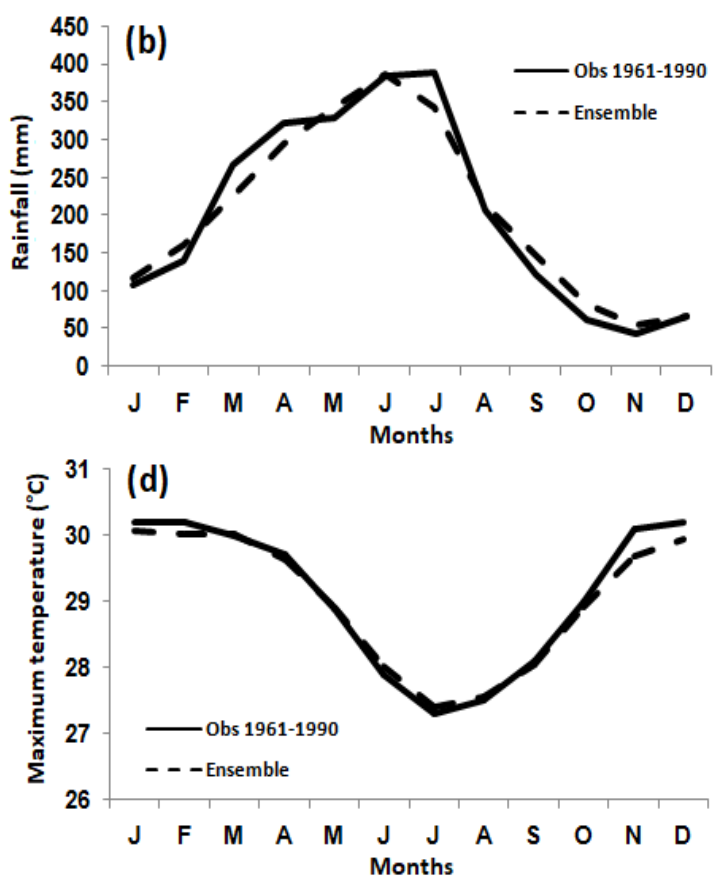

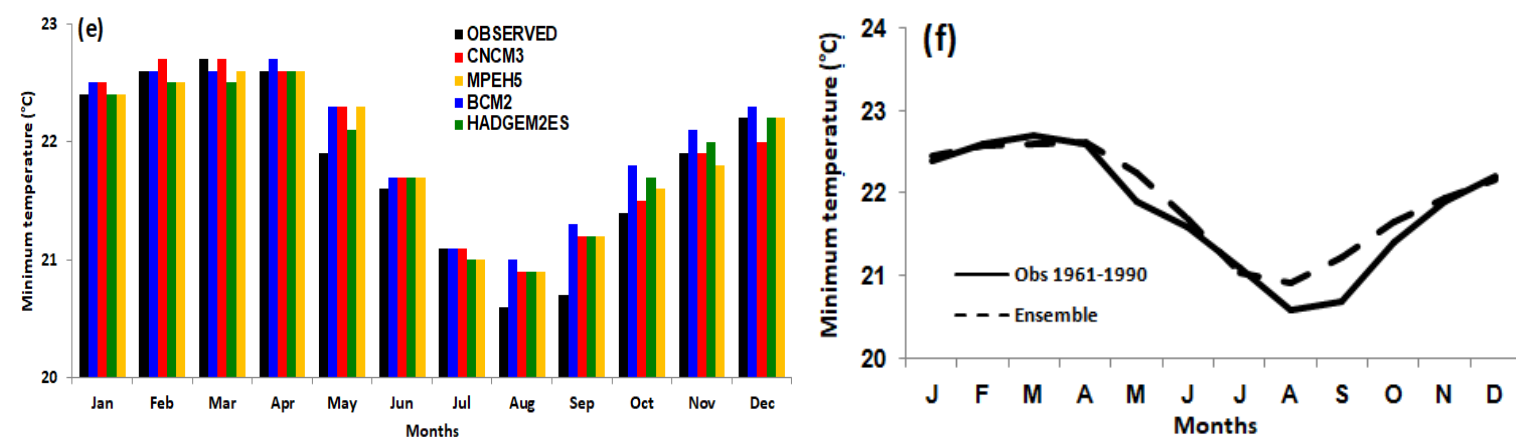

Figure 2 - Comparison between observed and simulated rainfall climatology by (a) CMIP3 GCMs and (b) ensemble models. The same for maximum temperature in (c) and (d), and minimum temperature in (e) and (f).
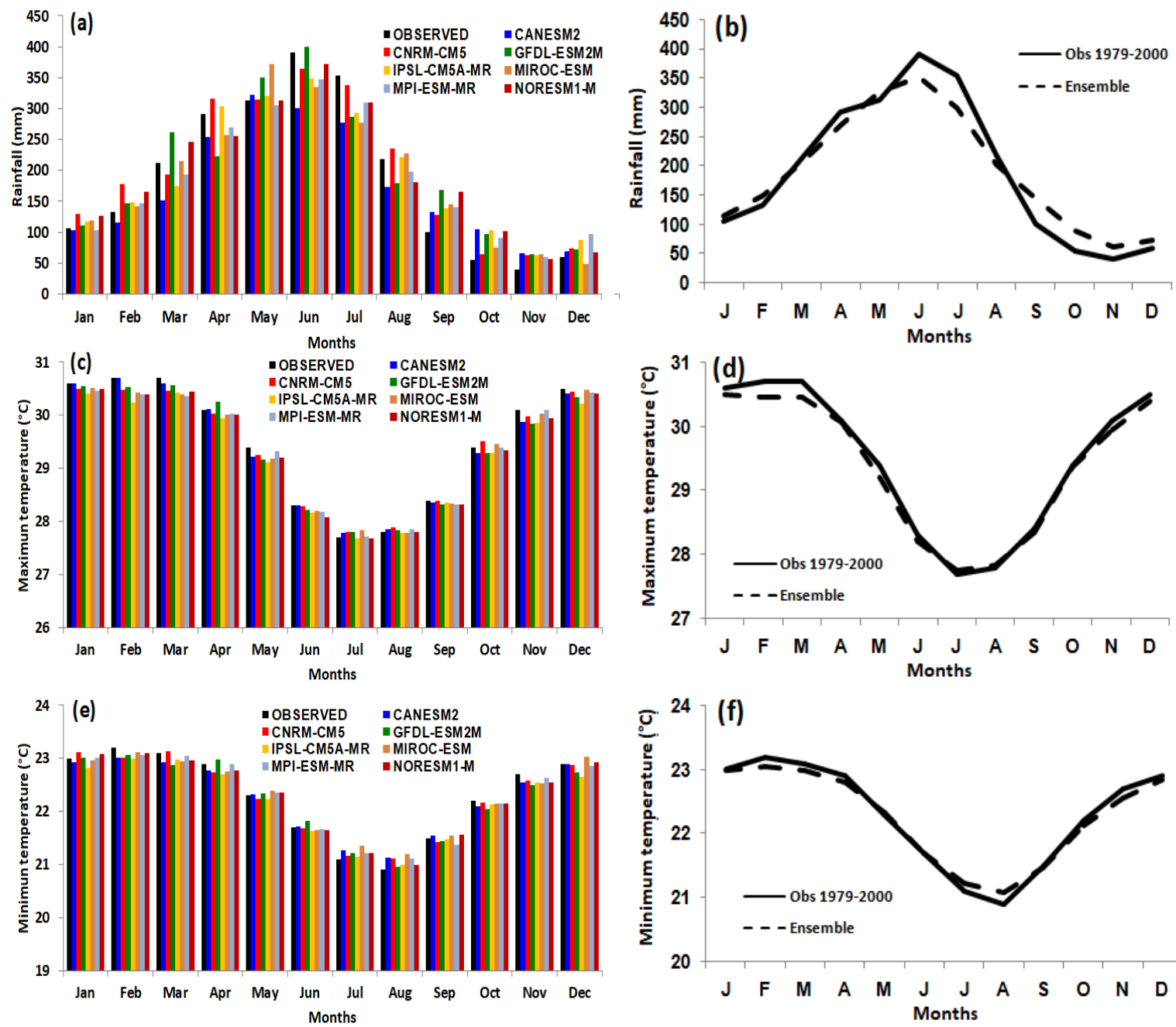

Figura 3 - Comparison between observed and simulated rainfall climatology by (a) CMIP5 GCMs and (b) ensemble models. The same for maximum temperature in (c) and (d), and minimum temperature in (e) and (f).

\section{GCMs Validation}

Table 2 shows a decendial validation of the statistical downscaling method calibration for the rainfall of the CMIP3 and CMIP5 models, then Tables 3 and 4 are for the maximum and minimum temperatures.

Rainfall obtained slightly superior performance for CMIP5 calibration. Mean and standard deviation values were very similar between observations and simulations. However, the correlation was higher than that of CMIP3, with smaller error, $\mathrm{RMSE}=6$ versus $\mathrm{RMSE}=7$ of CMIP3, a ratio of variances closer to 1 of CMIP5 and a slightly higher PDF score.

CMIP3 and CMIP5 had very similar performances at maximum temperatures, being slightly higher in CMIP3, with standard deviation lower than CMIP5. The minimum temperature was the variable with the highest performance difference between CMIP3 and CMIP5, with better performance 
in CMIP5, standing out in the correlation, variance ratio and PDFescore, which indicates a more homogeneous probability distribution function and similar to the observations. CMIP5.

Tabela 2 - Statistical performance measures for the rainfall validation period of CMIP3 and CMIP5. All correlation values were statistically significant at the $95 \%$ level by the t-student test.

\begin{tabular}{ccccccccc}
\hline Rainfall & $\bar{X}$ Obs & $\bar{X}$ Sim & S Obs & S Sim & $r$ & RMSE & $R V$ & PDFesc \\
\hline CMIP3 & 6,4 & 6,3 & 7,0 & 6,3 & 0,56 & 7,0 & 0,83 & 0,93 \\
CMIP5 & 6,2 & 6,1 & 6,6 & 6,5 & 0,67 & 6,0 & 0,96 & 0,96 \\
\hline
\end{tabular}

Tabela 3 - Same as Table 2, but for maximum temperatures.

\begin{tabular}{ccccccccc}
\hline Max. temp & $\bar{X}$ Obs & $\bar{X}$ Sim & S Obs & S Sim & $r$ & RMSE & RV & PDFesc \\
\hline CMIP3 & 29,2 & 29,1 & 1,3 & 1,1 & 0,85 & 0,7 & 0,78 & 0,89 \\
CMIP5 & 29,4 & 29,4 & 1,5 & 1,5 & 0,86 & 0,7 & 0,76 & 0,89 \\
\hline
\end{tabular}

Tabela 4 - Same as Table 2, but for minimum temperatures.

\begin{tabular}{ccccccccc}
\hline Min. temp & $\bar{X}$ Obs & $\bar{X}$ Sim & S Obs & S Sim & $r$ & RMSE & $R V$ & PDFesc \\
\hline CMIP3 & 22,0 & 22,1 & 1,1 & 0,8 & 0,57 & 0,9 & 0,52 & 0,86 \\
CMIP5 & 22,3 & 22,4 & 1,0 & 0,9 & 0,66 & 0,8 & 0,78 & 0,94 \\
\hline
\end{tabular}

Future Rainfall, Average Temperature, and ETP Scenarios for Recife

Figure 4 shows statistical downscaling results from CMIP3 future scenarios A1B and A2 for rainfall (upper panel, $\mathrm{a}$ and $\mathrm{b}$ ), average temperature (central panel, c and d) and ETP (lower panel, e and f). The results are shown for the ensemble of the models and shows a reduction of total annual rainfall for the period $2021-2050$ of $18.2 \%$ in the A1B scenario and $18.4 \%$ in the $\mathrm{A} 2$ scenario, and $21.8 \%$ and $23 \%$ over the period 2051-2080 for scenario A2. For rainfall, it is important to emphasize the considerable decrease of rainfall in the rainy season from March to August, but an increase of rainfall in the dry months, from September to February. The average temperatures, obtained from the maximum and minimum temperature scenarios, show similar behavior in scenarios A1B and A2, with average increase of $1.0^{\circ} \mathrm{C}$ between $2021-2050$ and 2.0 ${ }^{\circ} \mathrm{C}$ between 2051-2080. Responding to this temperature variation, the PET shows values from 10 to $35 \mathrm{~mm}$ higher than the reference period, in both scenarios and subperiods analyzed.
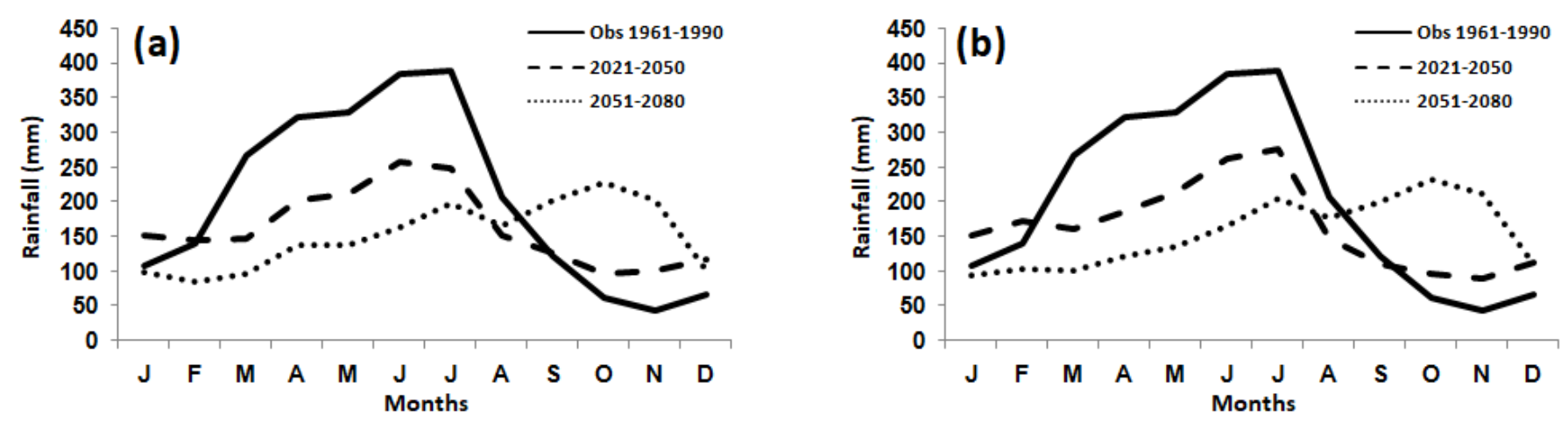

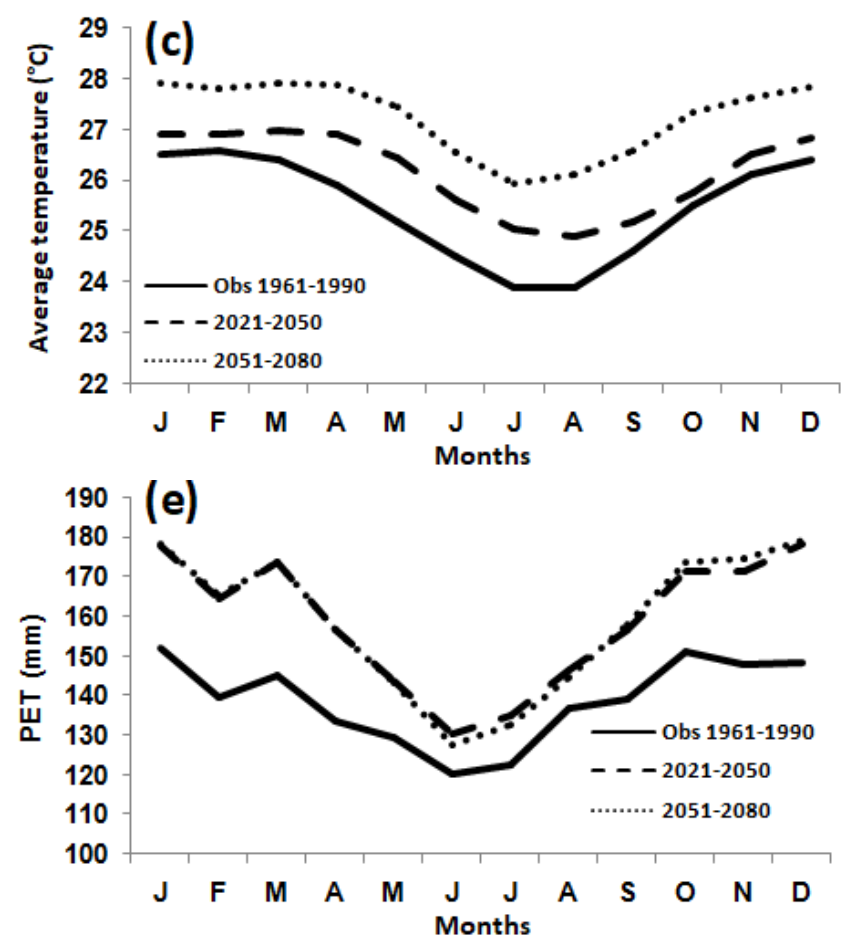
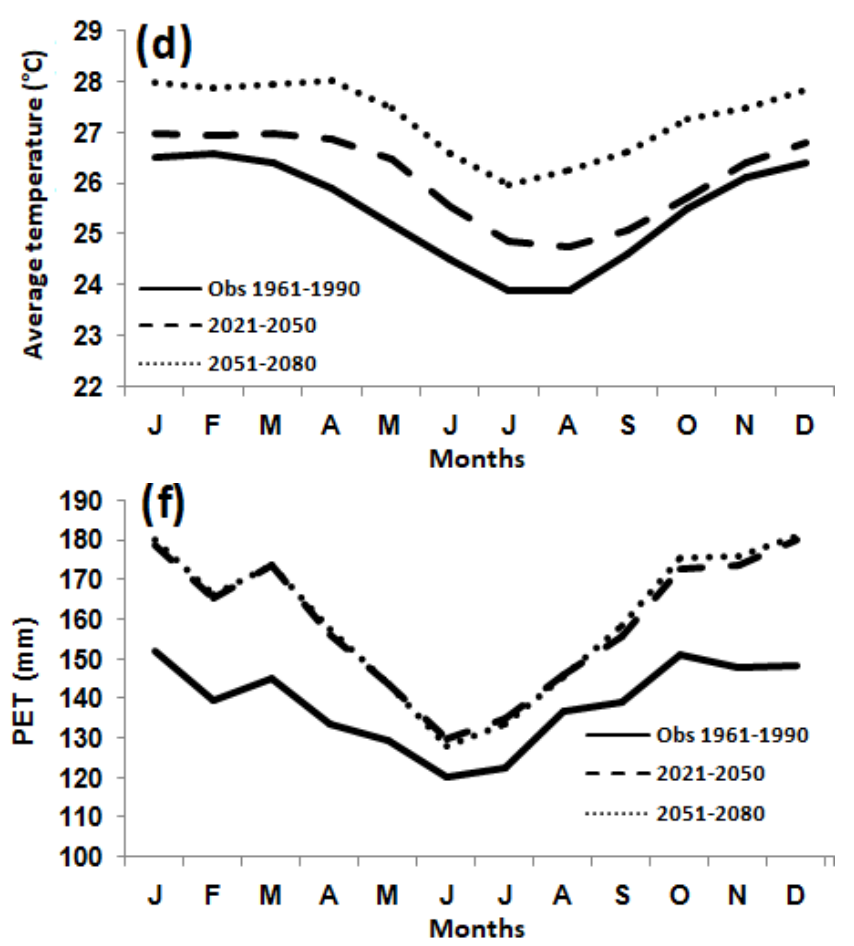

Figura 4 - Rainfall, average temperature and PET behavior for CMIP3 future scenarios A1B and A2.

Figure 5 shows the results of CMIP5 scenarios RCP4.5 and RCP8.5 for subperiods 2021-2050 and 2051-2080. In the RCP4.5 scenario the rainfall (upper panel, $\mathrm{a}$ and $\mathrm{b}$ ) is forecast to decrease by $5.2 \%$ compared to the 1979-2000 reference climatology, and by $15.4 \%$ between $2051-2080$, while in the RCP8.5 scenario these numbers increase to $8 \%$ and $46.1 \%$, respectively. The average temperature increase
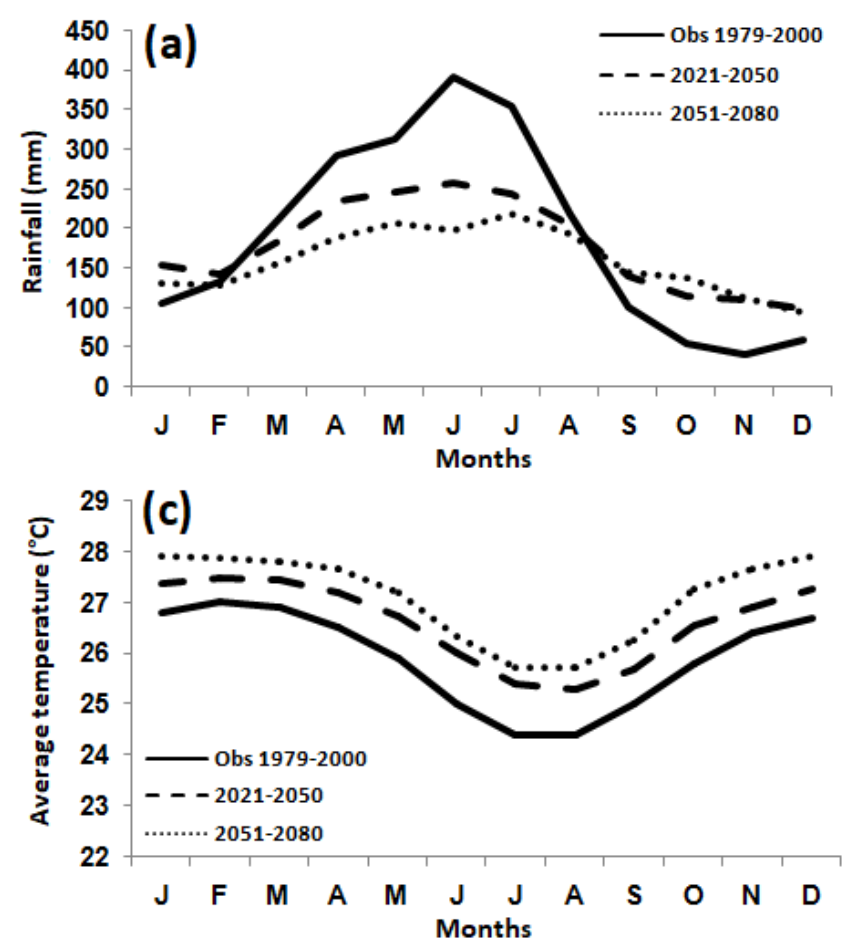

is projected to be around $0.8{ }^{\circ} \mathrm{C}$ and $1.3{ }^{\circ} \mathrm{C}$ in the RCP4.5 scenario and from 1.0 to $1.9^{\circ} \mathrm{C}$ in the RCP8.5 scenario, in each subperiod respectively. The PET in both scenarios and two subperiods maintains values close to the reference climatology, disagreeing with that observed in the results of CMIP3, where the PET followed the temperature increase presenting a considerable increase in relation to the observation.
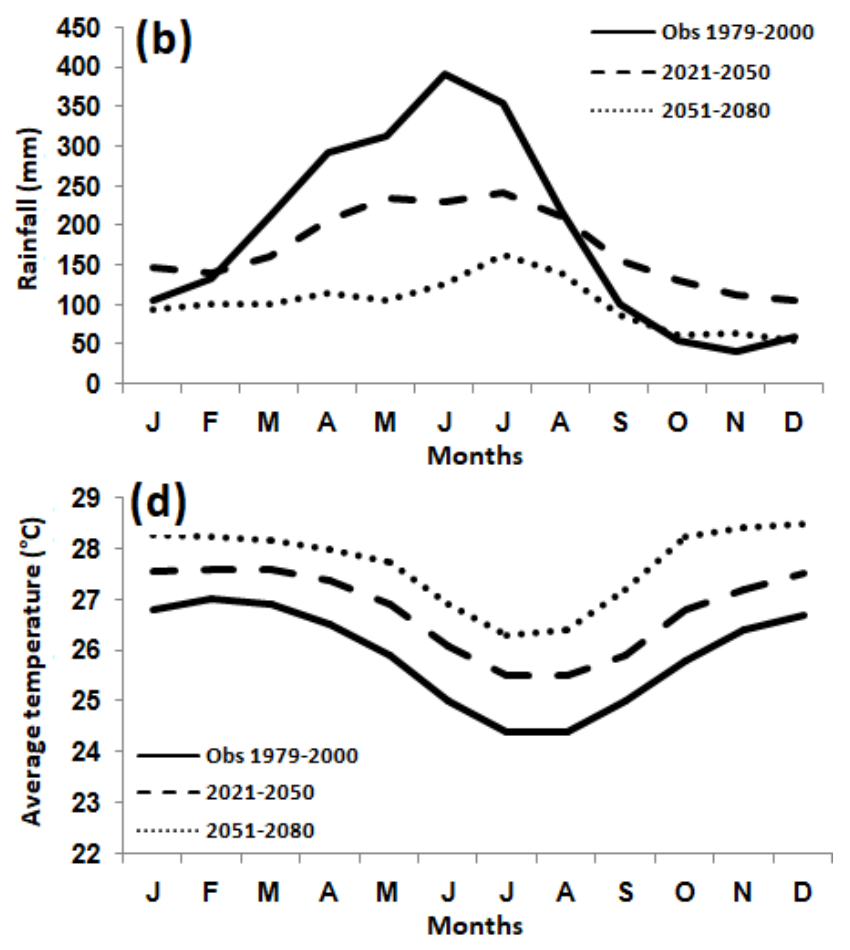

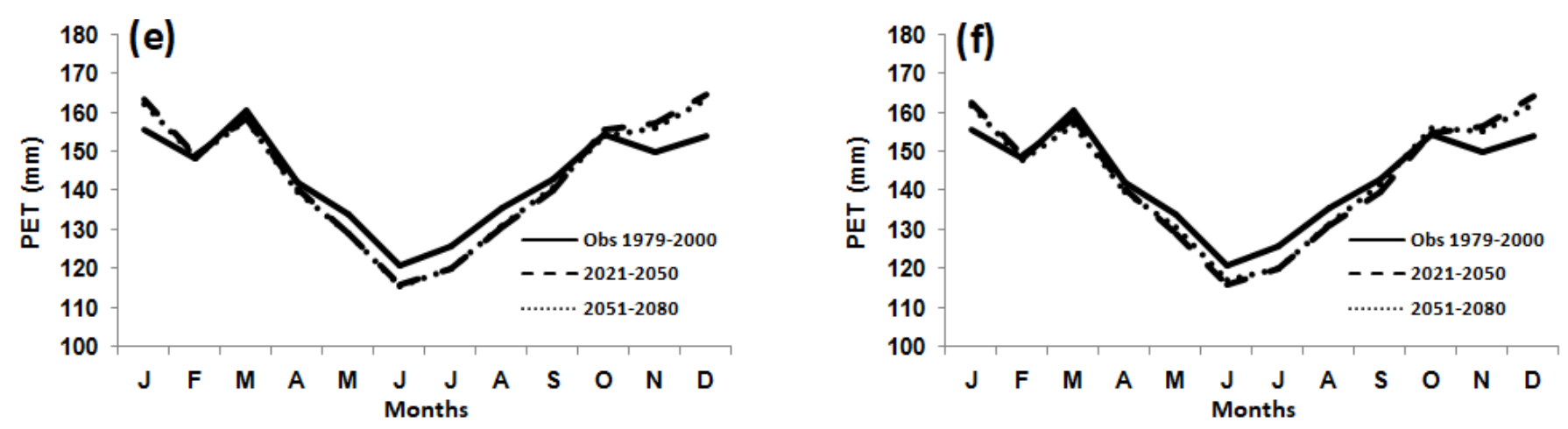

Figura 5 - Rainfall, average temperature and PET behavior for CMIP3 future scenarios RCP4.5 and RCP8.5.

In general, it is noted that the results from the different future regionalized climate change scenarios for Recife have similarities, except for the predicted behavior of the ETP and the high projected reduction of the total annual rainfall for the RCP8.5 scenario, much higher than too much. Similar comparative studies between CMIP3 and CMIP5 have been designed to show that, despite the evolution of GCMs, earlier versions can continue to be used for impact assessment and climate change mitigation studies. Sun et al. (2015) published a NOAA white paper entitled "Regional Surface Weather Conditions at CMIP3 and CMIP5 for the United States: Differences, Similarities, and Implications for the US National Climate Assessment." The overall conclusion of the study was that the similarities between CMIP3 and CMIP5 GCMs are much larger than their differences, with much more MCIPs in CMIP5 than CMIP3, which in some ways does not allow a more accurate comparison. Finally, that CMIP5 does not diminish in value the results obtained by CMIP3, and both have to be taken into account in the same way.

\section{Conclusions}

All CMIP3 and CMIP5 GCMs were able to represent the average annual rainfall cycle, maximum and minimum temperatures, and therefore average temperatures and ETP. CMIP5 was superior to CMIP3 in the climatological representation of rainfall and minimum and lower temperatures for maximum temperatures. However, the difference between the sets was very subtle.

Verification measures showed that the set of predictors chosen for statistical downscaling has the ability to satisfactorily reproduce the observed conditions.

Scenarios A1B and A2 underestimate rainfall in the rainy season between March and August, however there is a forecast increase for rainfall from September to December. In scenarios RCPs 4.5 and 8.5 similar behavior was observed, although the reduction in rainfall predicted in scenario RCP8.5 exceeds $40 \%$ in relation to the observed climatology.
In Recife scenarios $\mathrm{A} 1 \mathrm{~B}$ and $\mathrm{A} 2$ show increases of $0.5^{\circ} \mathrm{C}$ between $2021-2050$ and up to $2{ }^{\circ} \mathrm{C}$ between 2051 and 2080, in RCPs the average annual increase is around $1.5^{\circ} \mathrm{C}$.

In Recife, scenarios A1B and $\mathrm{A} 2$ are expected to increase by up to $30 \mathrm{~mm}$ in the warmer months, while in the RCPs the monthly average PET values change little in relation to the reference climatology.

\section{Acknowledgements}

The present work was carried out with the support of the Higher Education Personnel Improvement Coordination - Brazil (CAPES). The first author is grateful for the grant of the Post Doctorate scholarship at ICAT/UFAL.

\section{References}

Allen, R.G., Pereira, L.S., Raes, D., Smith, M., 1998. Crop evapotranspiration - Guidelines for computing crop water requirements - FAO Irrigation and drainage paper 56.

Arora, V.K., Boer, G.J., Christian, J.R., Curry, C.L., Denman, K.L., Zahariev, K., Flato, G.M., Scinocca, J.F., Merryfield, W.J., Lee, W.G., 2009. The effect of terrestrial photosynthesis down regulation on the twentieth-century carbon budget simulated with the CCCma Earth System Model. Journal of Climate 22, 6066-6088.

Arora, V.K., Boer, G.J., 2010. Uncertainties in the 20th century carbon budget associated with land use change. Global Change Biology 16, 33273348.

Bellouin, N., Boucher, O., Haywood, J., Johnson, C., Jones, A., Rae, J., Woodward, S., 2007. Improved representation of aerosols for HadGEM2. Meteorological Office Hadley Centre, Technical Note 73.

Bentsen, M., Bethke, I., Debernard, J. B., Iversen, T., Kirkevåg, A., Seland, Ø., Drange, H., Roelandt, C., Seierstad, I. A., Hoose, C., Kristjánsson, J. E., 2012. The Norwegian Earth System Model, NorESM1-M - Part 1: description and basic 
evaluation of the physical climate. Geoscientific Model Development 6, 687-720.

Borges, M.A.L., Silva, H.P., Caldas, K.F.R., 2016. Mapeamento de Pernambuco frente aos desastres naturais - uma análise socioeconômica. ACTA Geográfica 57-72.

Carvalho, J.R.P., Nakai, A.M., Monteiro, J.E.B.A., 2016. Spatio-temporal modeling of data imputation for daily rainfall series in homogeneous zones. Revista Brasileira de Meteorologia 31, 196-201.

Clarke, L.E., Edmonds, J.A., Jacoby, H.D., Pitcher, H., Reilly, J.M., Richels, R., 2007. Scenarios of greenhouse gas emissions and atmospheric concentrations. Sub-report 2.1a of Synthesis and Assessment Product 2.1. Climate Change Science Program and the Subcommittee on Global Change Research, Washington DC.

Cofiño, A.S., San-Martin, D., Gutiérrez, J.M., 2007. A web portal for regional projection of weather forecast using GRID middleware. Santander Meteorology Group.

Collins, W.J., Bellouin, N., Doutriaux-Boucher, M., Gedney, N., Hinton, T.C., Jones, D., Liddicoat, S., Martin, G., Oconnor, F., Rae, J., Senior, C., Totterdell, I., Woodward, S., 2008. Evaluation of the HadGEM2 model. Meteorological Office Hadley Centre, Technical Note 74.

Dee, D.P., Uppala, S.M., Simmons, A.J., Berrisford, P., Poli, P., Kobayashi, S., Andrae, U., Balmaseda, M.A., Balsamo, G., Bauer, P., Bechtold, P., Beljaars, A.C.M., van de Berg, L., Bidlot, J., Bormann, N., Delsol, C., Dragani, R., Fuentes, M., Geer, A.J., Haimberger, L., Healy, S.B., Hersbach, H., Holm, E.V., Isaksen, L., Kallberg, P., Kohler, M., Matricardi, M., McNally, A.P., Monge-Sanz, B.M., Morcrette, J.J., Park, B.K., Peubey, C., Rosnay, P., Tavolato, C., Thepaut, J.N., Vitart, F., 2011. The ERA-Interim reanalysis: configuration and performance of the data assimilation system. Quarterly Journal of the Royal Meteorological Society 137, 553-597.

Dufresne, J.L., Foujols, M.A., Denvil, S., Caubel, A., Marti, O., Aumont, O., Balkanski, Y., Bekki, S., Bellenger, H., Benshila, R., Bony, S., Bopp, L., Braconnot, P., Brockmann, P., Cadule, P., Cheruy, F., Codron, F., Cozic, A., Cugnet, D., de Noblet, N., Duvel, J.P., Ethe, C., Fairhead, L., Fichefet, T., Flavoni, S., Friedlingstein, P., Grandpeix, J.Y., Guez, L., Guilyardi, E., Hauglustaine, D., Hourdin, F., Idelkadi, A., Ghattas, J., Joussaume, S., Kageyama, M., Krinner, G., Labetoulle, S., Lahellec, A., Lefevre, M.P., Lefevre, F., Levy, C., Li, Z.X., Lloyd, J., Lott, F., Madec, G., Mancip, M., Marchand, M., Masson, S., Meurdesoif, Y., Mignot, J., Musat, I., Parouty, S., Polcher, J., Rio, C., Schulz, M., Swingedouw, D., Szopa, S., Talandier, C., Terray, P., Viovy, N., Vuichard, N.,
2013. Climate change projections using the IPSLCM5 Earth System Model: from CMIP3 to CMIP5. Climate Dynamics 40, 2123-2165.

Dunne, J.P., John, J.G., Adcroft, A.J., Griffies, S.M., Hallberg, R.W., Shevliakova, E., Stouffer, R.J., Cooke, W., Dunne, K.A., Harrison, M.J., Krasting, J.P., Malyshev, S.L., Milly, P.C.D., Phillipps, P.J., Sentman, L.T., Samuels, B.L., Spelman, M.J., Winton, M., Wittenberg, A.T., Zadeh, N., 2012. GFDL's ESM2 Global Coupled Climate-Carbon Earth System Models. Part I: physical formulation and baseline simulation characteristics. Journal of Climate 25, 6646-665.

Dunne, J.P., John, J.G., Shevliakova, E., Stouffer, R.J., Krasting, J.P., Malyshev, S.L., Milly, P.C.D., Sentman, L.T., Adcroft, A.J., Cooke, W., Dunne, K.A., Griffies, S.M., Hallberg, R.W., Harrison, M.J., Levy, H., Wittenberg, R.W., Phillips, P.J., Zadeh, N., 2013. GFDL's ESM2 Global Coupled Climate-Carbon Earth System Models. Part II: carbon system formulation and baseline simulation characteristics. Journal of Climate 26, 2247-2267.

Fujino, J., Nair, R., Kainuma, M., Masui, T., Matsuoka, Y., 2006. Multigas mitigation analysis on stabilization scenarios using aim global model. The Energy Journal 3, 343-354.

Giorgetta, M.A., Jungclaus, J., Reick, C.H., Legutke, S., Bader, J., Bottinger, M., Brovkin, V., Crueger, T., Esch, M., Fieg, K., Glusnak, K., Gayler, V., Haak, H., Hollweg, H-D., Ilyina, T., Kinne, S., Kornblueh, L., Matei, D., Mauritsen, T., Mikolajewicz, U., Mueller, W., Notz, D., Pithan, F., Raddatz, T., Rast, S., Redler, R., Roechner, E., Schmidt, H., Schnur, R., Segschneider, J., Six, K.D., Stockhause, M.,Timmreck, C., Wegner, J., Widmann, H., Wieners, K-H., Claussen, M., Marotzke, J., Stevens, B., 2013. Climate and carbon cycle changes from 1850 to 2100 in MPIESMsimulations for the Coupled Model Intercomparison Project phase 5. Journal of Advances in Modeling Earth Systems 5, 572-597.

Guimarães, S.O, Costa, A.A, Junior, F.C.V, Silva, E.M, Sales, D.C, Junior, L.M.A, Souza, S.G., 2016. Projeções de mudanças climáticas sobre o nordeste brasileiro dos modelos do CMIP5 e do CORDEX. Revista Brasileira de Meteorologia 31, 337-365.

Guo, C., Bentsen, M., Bethke, I., Ilicak, M., Tjiputra, J., Toniazzo, T., Schwinger, J., Ottera, O.H., 2019. Description and evaluation of NorESM1-F: a fast version of the Norwegian Earth System Model (NorESM). Geoscientific Model Development 12, 343-362.

Gutiérrez, J.M., San-Martin, D., Brands, S., Manzanas, R., Herrera, S., 2013. Reassessing statistical downscaling techniques for their robust application under climate change conditions. Journal of Climate 26, 171-188. 
Hartmann, D.L., Klein-Tank, A.M.G., Rusticucci, M., Alexander, L.V., Bronnimann, S., Charabi, Y., Dentener, F.J., Dlugokencky, E.J., Easterling, D.R., Kaplan, A., Soden, B.J., Thorne, P.W., Wild, M., Zhai, P.M., 2013. Observations: Atmosphere and Surface. In The Physical Science Basis. Contribution of Working Group I to the Fifth Assessment Report of the Intergovernmental Panel on Climate Change, 159-254.

Hijioka, Y., Matsuoka, Y., Nishimoto, H., Masui, T., Kainuma, M., 2008 Global GHG emission scenarios under GHG concentration stabilization targets. Journal of Global Environment Engineering 13, 97-108.

Hargreaves, G.H., Samani, Z.A., 1985. Reference crop evapotranspiration from temperature. Applied Engineering in Agriculture 1, 96-99.

Iversen, T., Bentsen, M., Bethke, I., Debernard, J.B., Kirkevåg, A., Seland, Ø., Drange, H., Kristjansson, J.E., Medhaug, I., Sand, M., Seierstad, I.A., 2013. The Norwegian Earth System Model, NorESM1-M - Part 2: climate response and scenario projections, Geoscientific Model Development 6, 389-415.

Jones, R.G., Noguer, M., Hassel, D.C., Hudson, D., Wilson, S.S., Jenkins, G.J., Mitchell, J.F.B., 2004. Generating High Resolution Climate Change Scenarios Using PRECIS. Meteorological Office Hadley Centre, Exeter.

Jungclaus, J.H., Fischer, N., Haak, H., Lohmann, K., Marotzke, J., Matei, D., Mikolajewicz, U., Notz, D., von Storch, J.S., 2013. Characteristics of the ocean simulations in the Max Planck Institute Ocean Model (MPIOM) the ocean component of the MPI-Earth system model. Journal of Advances in Modeling Earth Systems 5, 422-446.

Marengo, J.A., Jones, R., Alves, L.M., Valverde, M.C., 2009. Future change of temperature and precipitation extremes in South America as derived from the PRECIS regional climate modeling system. International Journal of Climatology 29, 2241-2255.

Marsland, S.J., Haak, H., Jungclaus, J.H., Latif, M., Roeske, F., 2003. The Max-Planck-Institute global ocean/sea ice model with orthogonal curvilinear coordinates. Ocean Modelling 5, 91-127.

Muller, W.A., Jungclaus, J.H., Mauritsen, T., Baehr, J., Bittner, M., Budich, R., Bunzel, F., Esch, M., Ghosh, R., Haak, H., Ilyina, T., Kleine, T., Kornblueh, L., Li, H., Modali, K., Dotz, D., Pohlmann, H., Roeckner, E., Stemmler, I., Tian, F., Marotzke, J.A., 2018. Higher-resolution Version of the Max Planck Institute Earth System Model (MPI-ESM1.2-HR). Journal of Advances in Modeling Earth Systems. doi: 10.1029/2017MS001217, p. 1383-1413.

Nakicenovic, N., Alcamo, J., Davis, G., de Vries, B., Fenhann, J., Gaffin, S., Gregory, K., Grübler, A.,
Jung, T.Y., Kram, T., la Rovere, E.L., Michaelis, L., Mori, S., Morita, T., Pepper, W., Pitcher, H, Price, L., Raihi, K., Roehrl, A., Rogner, H.H., Sankivski, A., Schlesinger, M., Shukla, P., Smith, S., Swart, R., van Rooijen, S, Victor, N., Dadi, Z., 2000. IPCC: Special Reporto $\mathrm{n}$ Emissions Scenarios. Cambridge University Press, Cambridge, United Kingdom, New York.

Nozawa, T., Nagashima, T., Ogura, T., Yokohata, T., Okada, N., Shiogama, H., 2007. Climate change simulations with a coupled ocean-atmosphere GCM called the Model for Interdisciplinary Research on Climate: MIROC, CGER Supercomput. Monogr. Rep., 12, Cent. For Global Environ. Res., Natl. Inst. for Environ. Stud., Tsukuba, Japan.

Prefeitura do Recife. A cidade do Recife: perfil e História. Disponível: http://www.recife.pe.gov.br/pr/secplanejamento/in forec/. Acesso: 8 jul. 2008.

Raddatz T.J., Reick, C.H., Knorr, W., Kattge, J., Roeckner, E., Schnur, R., Schnitzler, K.-G., Wetzel, P., Jungclaus, J., 2007. Will the tropical land biosphere dominate the climate-carbon cycle feedback during the twenty first century? Climate Dynamics 29, 565-574.

Riahi, K., Grübler, A., Nakicenovic, N., 2007. Scenarios of long-term socio-economic and environmental development under climate stabilization. Technological Forecasting and Social Change 74, 887-935.

Riahi, K., Krey, V., Rao, S., Chirkov, V., Fischer, G., Kolp, P., Kindermann, G., Nakicenovic, N., Rafai, P., 2011. RCP-8.5: exploring the consequence of high emission trajectories. Climatic Change. doi: 10.1007/s10584-011-0149-y.

Salas-Mélia, D., 2002. A global coupled sea ice-ocean model. Ocean Modelling 4, 137-172.

Salas-Mélia, D., Chauvin, F., Déqué, M., Douville, H., Gueremy, J. F., Planton, S., Royer, J. F., Tyteca, S., 2005. Description and validation of the CNRMCM3 global coupled model. CNRM Tech. Rep. 103.

Sales, D.C, Costa, A.A, Silva, E.M, Junior, F.C.V, Cavalcante, A.M.B, Medeiros, S.S, Marin, A.M.P, Guimarães, S.O, Junior, L.M.A, Pereira, J.M.R., 2015. Projeções de mudanças na precipitação e temperatura no nordeste brasileiro utilizando técnica de downscaling dinâmico. Revista Brasileira de Meteorologia 30, 435 - 456.

Salviano, M.F., Groppo, J.D., Pelegrino, G.Q., 2016. Análise de tendências em dados de precipitação e temperatura no Brasil. Revista Brasileira de Meteorologia 31, 64-73.

Samani, Z., 2000. Estimating solar radiation and evapotranspiration using minimum climatological 
data. Journal of Irrigation and Drainage Engineering 126, 265-267.

Silva, V.B.S., Kousky, V.E., Silva, F.D.S., Salvador, M.A., Aravequia, J.A., 2013. The 2012 severe drought over Northeast Brazil. Bulletin of the American Meteorological Society 94, 162.

Silva, F.D.S., Ramos, R.M., Costa, R.L., Azevedo, P.V., 2014. Sistema de controle de qualidade para dados diários de variáveis meteorológicas. Revista Brasileira de Geografia Física 7, 827-836.

Smith, S.J., Wigley, T.M.L, 2006. MultiGas forcing stabilization with minicam. The Energy Journal 3, 373-392.

Souza, W.M., Azevedo, P.V., Assis, J.M.O., Sobral, M.C., 2014. Áreas de risco mais vulneráveis aos desastres decorrentes das chuvas em Recife-PE. Revista Brasileira de Ciências Ambientais 34, 7994.

SRES, 2010. Esmissions Scenarios: a special reporto on esmissions scenarios. IPCC Working Group III. Published for the Intergovernmental Panel on Climate Change. Cambridge University Press, Cambridge.

Sun, L., Kunkel, K.E., Stevens, L.E., Buddenberg, A., Dobson, J.G., Easterling, D.R., 2015. Regional Surface Climate Conditions in CMIP3 and CMIP5 for the United States: differences, similarities, and implications for the U.S. National Climate Assessment, NOAA Technical Report NESDIS 144. doi: 10.7289/V5RB72KG.

Taylor, K.E., Stouffer, R.J., Meehl, G.A., 2012. An Overview of CMIP5 and the Experiment Design. Bulletin of the American Meteorological Society. doi:10.1175/BAMS-D-11-00094.1.

Vannitsem, S., Chomé, F., 2005. One-way nested regional climate simulations and domain size. Journal of Climate 18, 229-233.

van Vuuren, D.P., Eickhout, B., Lucas, P.L., den Elzen, M.G.J., 2006. Long-term multi-gas scenarios to stabilise radiative forcing-exploring costs and benefits within an integrated assessment framework. Energy Journal 27, 201-233.

van Vuuren, D.P., den Elzen, M.G.J., Lucas, P.L., Strengers, B.J., van Ruijven, B., Wonink, S., van Houdt, R., 2007a. Stabilizing greenhouse gas concentrations at low levels: an assessment of reduction strategies and costs. Climatic Change 81, 119-159.

van Vuuren, D.P., Lucas, P. L., Hilderink, H., $2007 b$. Downscaling drivers of global environmental change: enabling use of global SRES scenarios at the national and grid levels. Global Environmental Change 17, 114-130.

van Vuuren, D.P., Edmonds, J., Kainuma, M., Riahi, K., Thomson, A., Hibbard, K., Hurtt, G.C., Kram, T., Krey, V., Lamarque, J.F., Masui, T., Meinshausen, M., Nakicenovic, N., Smith, S.J., Rose, S.K., 2011. The representative concentration pathways: an overview. Climatic Change. doi: 10.1007/s10584-011-0148-z.

Voldoire, A.E., Sanchez-Gomez, D., Salas y Mélia, B., Decharme, C., Cassou, S., Sénési, S., Valcke, I., Beau, A., Alias, M., Chevallier, M., Déqué, J., Deshayes, H., Douville, E., Fernandez, G., Madec, E., Maisonnave, M. P., Moine, S., Planton, D., Saint-Martin, S., Szopa, S., Tyteca, R., Alkama, S., Belamari, A., Braun, L., Coquart, F., Chauvin, F., 2011. The CNRM-CM5.1 global climate model: description and basic evaluation. Climate Dynamics 40, 2091-2121.

Watanabe, S., Hajima, T., Sudo, K., Nagashima, T., Takemura, T., Okajima, H., Nozawa, T., Kawase, H., Abe, M., Yokohata, T., Ise, T., Sato, H., Kato, E., Takata, K., Emori, S., Kawamiya, M., 2011. MIROC-ESM 2010: model description and basic results of CMIP5-20c3m experiments. Geoscientific Model Development 4, 845-872.

Wilby, R.L., Dawson, C.W., 2013. The Statistical DownScaling Model (SDSM): Insights from one decade of application. International Journal of Climatology 33, 1707-1719.

Wise, M., Calvin, K., Thomson, A., Clarke, L., BondLamberty, B., Sands, R., Smith, S. J., Janetos, A., Edmonds, J. Implications of limiting $\mathrm{CO} 2$ concentrations for land use and energy. Science 324, 1183-1186.

Zahariev, K., Christian, J. R., Denman, K. L., 2008. Preindustrial, historical, and fertilization simulations using a global ocean carbon model with new parameterizations of iron limitation, calcification, and N2 fixation. Progress in Oceanography 77, 56-82. 